\section{Sediment deposits in the Cape Basin: Indications for shifting ocean currents?}

\section{Estella Weigelt and Gabriele Uenzelmann-Neben}

\begin{abstract}
The Benguela Current system, running off southwest Africa, is one of the world's largest upwelling regions. The current has strongly influenced sedimentary features on the continental margin. To unravel its development, seismic stratigraphy, tied to drilling results from Ocean Drilling Program Leg 175 sites 1085-1087, was established. Four units, Southern Cape Basin (SCB)-1 to SCB-4, were defined for the Cenozoic sediments. The upper unit, SCB-1 $(<1.5 \mathrm{Ma})$, characterized by continuous high-amplitude reflectors, represents global cooling and glacial-interglacial cycles. Unit SCB-2 (<14 Ma), distinguished by low-amplitude reflections, is associated with the onset of the upwelling system and establishment of the modern circulation pattern in the Cape Basin. Slump scarps are concentrated along the middle and upper shelf slope, suggesting they are caused by a combination of mass movements triggered by bottom currents and slope instabilities because of increased deposition associated with the upwelling. A westward extension and/or movement of upwelling filaments is interpreted from the observed seaward shift of scarp locations with time. Erosion associated with stronger currents probably thinned unit SCB-2 in the south. The two lower units, SCB-3 and SCB-4 (<56 Ma), probably represent material eroded from the shelf break and deposited during a major Oligocene-early Miocene regression that is consistent with a significant uplift of southern Africa. The basal reflector SCB-D of unit SCB-4 is associated with the prominent reflector $\mathrm{D}$ or $\mathrm{L}$ described in previous publications.
\end{abstract}

\section{BACKGROUND}

\section{Introduction}

The Cape Basin, part of the south Atlantic, is the setting of a complex pattern of oceanic circulation (Figure 1). The evolution of these

Copyright (C)2004. The American Association of Petroleum Geologists. All rights reserved. Manuscript received April 16, 2002; revised manuscript received July 7, 2003; final acceptance January 26, 2004

\section{AUTHORS}

ESTELLA WEIGELT $\sim$ Alfred Wegener Institute for Polar and Marine Research, Postfach 120161, 27515 Bremerhaven, Germany

After receiving her diploma in geophysics, geology, mineralogy, and physics at J. W. Goethe University in Frankfurt (1989), Estella Weigelt joined the Alfred Wegener Institute (AWI). After an overwintering campaign in the Antarctic advising a geophysical observatory for 14 months, she worked on her Ph.D. on seismic and gravity investigations of the Eurasian Basin. Since then, she has specialized on climate signals in marine sediments recorded in reflection seismics.

Gabriele Uenzelmann-Neben $\sim$ Alfred Wegener Institute for Polar and Marine Research, Postfach 120161, 27515 Bremerhaven, Germany

After receiving her diploma in geophysics, physical oceanography, geology, and physics at Hamburg University (1985), Gabriele UenzelmannNeben went to Kiel University and started working toward her Ph.D. on high-resolution seismic reflection investigations of the Voring Margin. In 1989, Uenzelmann-Neben joined AWI and has since specialized on sediment transport, sediment drifts, and obstacles for oceanic currents such as oceanic plateaus and ridges.

\section{ACKNOWLEDGEMENTS}

We are grateful for the support and assistance of the officers and crew of R/V Meteor on cruise $34 / 1, U$. Bleil (chief scientist) and the team of Ocean Drilling Program (ODP) Leg 175. V. Spiess provided us with information on the physical properties of the cores. This research used samples and/or data provided by the ODP. The ODP is sponsored by the U.S. National Science Foundation and participating countries under management of Joint Oceanographic Institutions, Inc. Funding for this research was provided by the Deutsche Forschungsgemeinschaft under contract number Ue 49/4. This is AWI contribution number awi-n11195. 


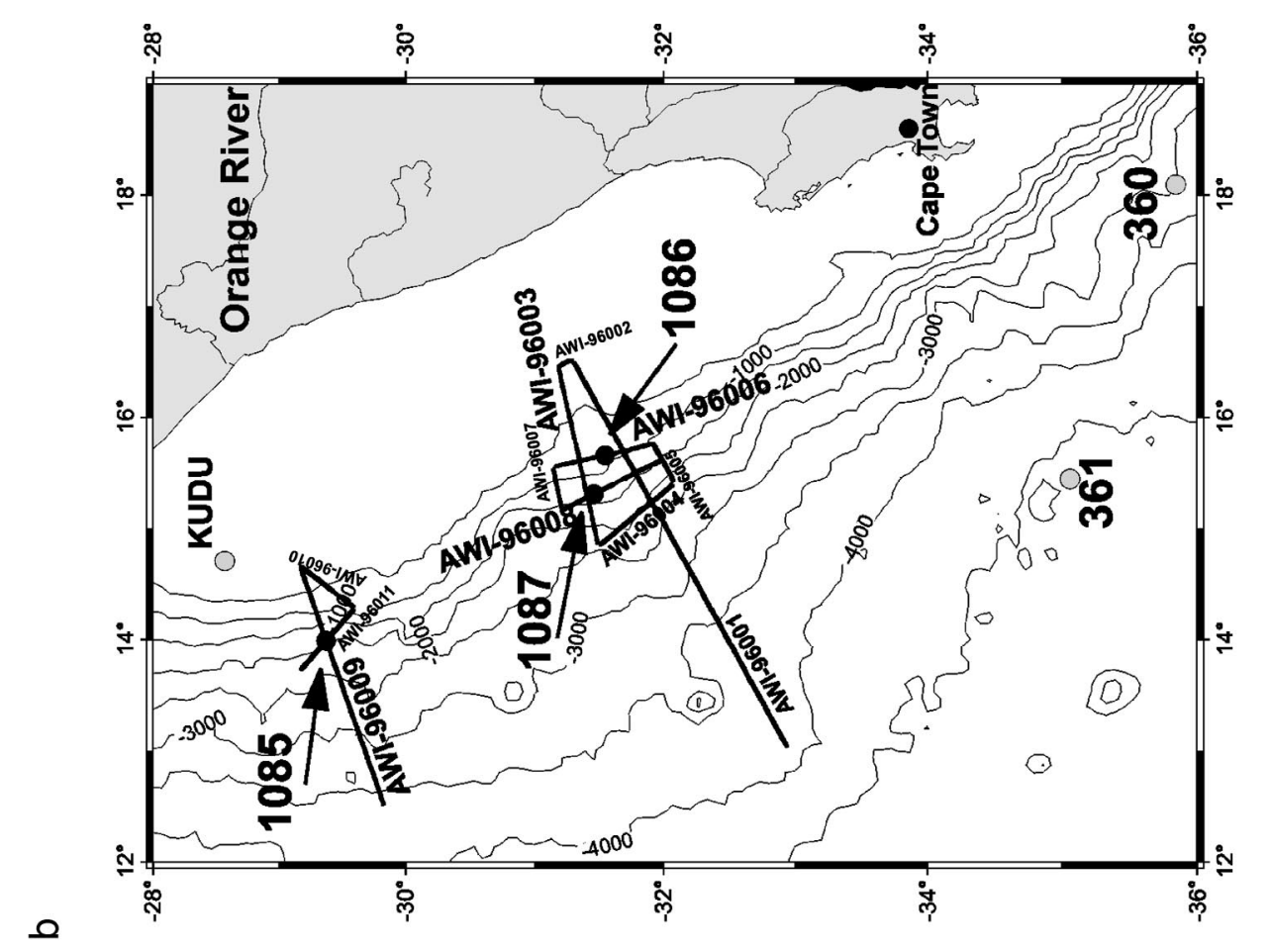

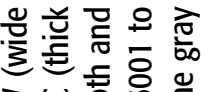

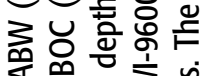

这会资

ปิ่

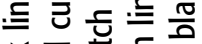

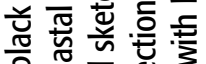

.

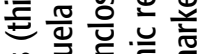

๘

呈㐫号脑

늘

产 궁

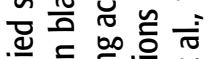

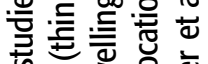

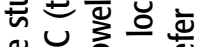

Ð

प一

흘 흘 윻 홍응 은 으 든

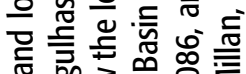
ํㅜㄴ

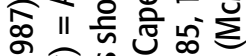

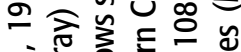

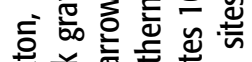

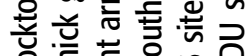
放至

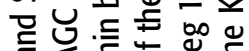

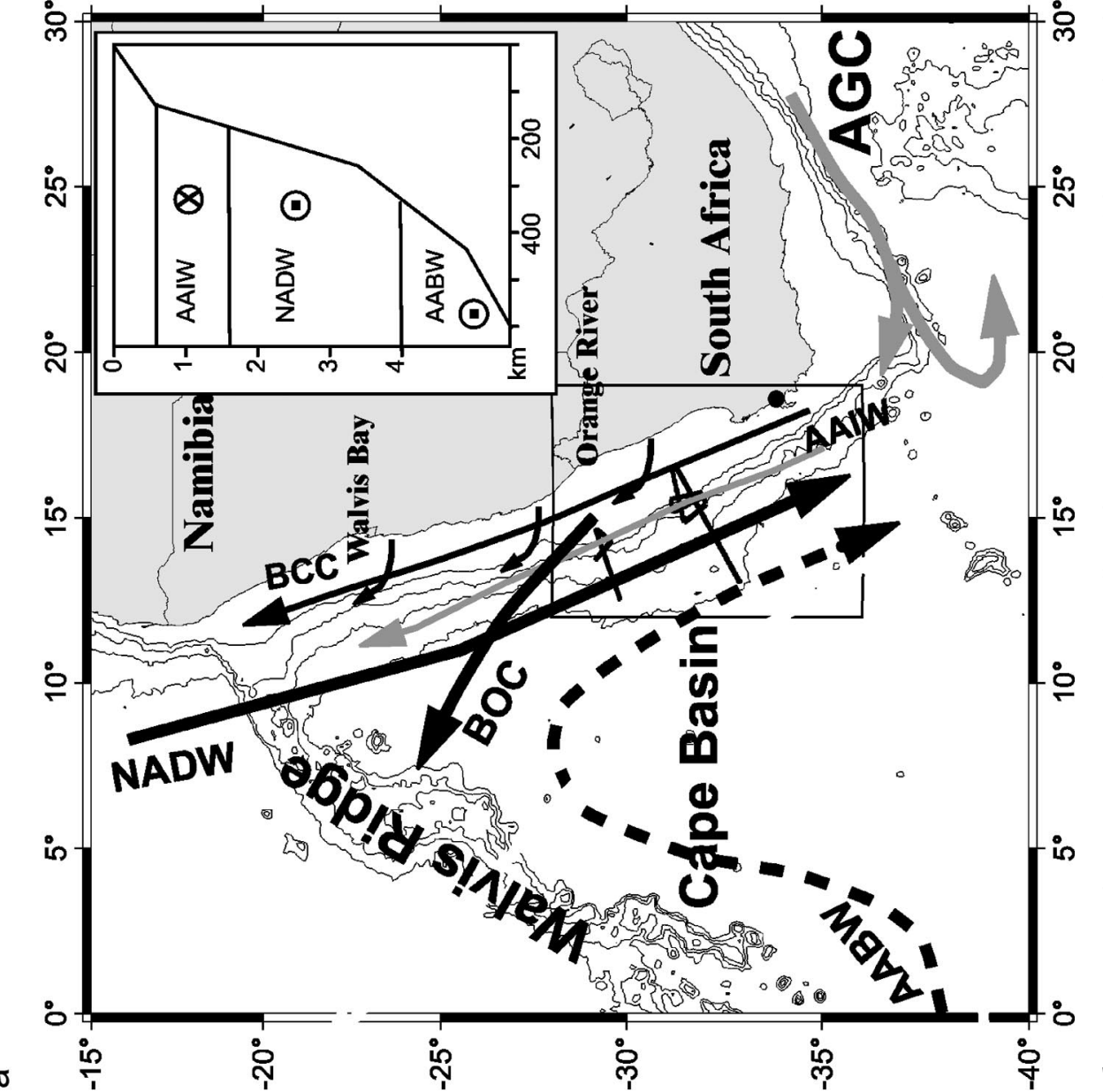

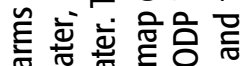

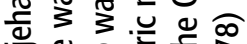

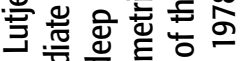
屯 प्रे थं 흉

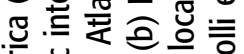

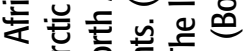

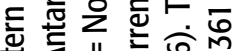

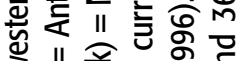
ॐ

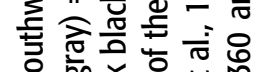

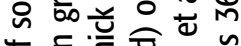

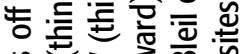

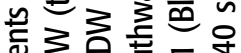

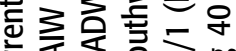
产文㶽品 已. $=$ II $\sum^{m}$

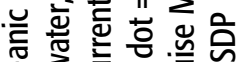

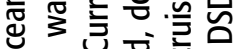
व $\varepsilon$ 눈

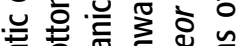

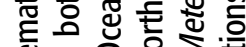
는 은 윰 式 (త) - II

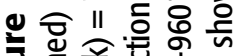

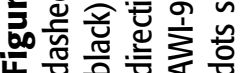


oceanic currents is related to the evolution of the $\mathrm{Ne}-$ ogene climate of the southern hemisphere and left a significant imprint in the sedimentary structures of the southwest African margin (e.g., Wefer et al., 1998). Part of this current system is the Benguela Current upwelling system. Because of its high productivity and sedimentation rates, it has the potential to be an excellent climate archive and offers the possibility to study the evolution of the circulation system in the southern Cape Basin. Significant events, such as incursions of warm or cold waters, climate changes, and slumps, are recorded in the deposited sediments (Wefer et al., 1998). Changes in sedimentary properties are expected to be reflected in the character of seismic data. However, most seismic studies of the southwest African margin have concentrated on the breakup history, the continental-oceanic crustal transition (e.g., Emery et al., 1975; Austin and Uchupi, 1982), or the structural and sedimentary evolution on a larger timescale (e.g., Dingle and Robson, 1992) and ignore the fine stratigraphic details that would give clues to climate. High-resolution seismic data suitable for a detailed study were gathered on R/V Meteor cruise 34/1 (Bleil et al., 1996). Additionally, ground-truth information is available from Ocean Drilling Program (ODP) Leg 175 drilling data (Wefer et al., 1998). Changes in the current systems are reflected by seismic attributes and structures of mass movements or hiati and can be identified on the spatial image of reflection seismic lines.

The objectives of our study are to generate (1) a high-resolution seismostratigraphic model for the Cenozoic, by associating the drilling results to the seismic sections via synthetic seismograms and (2) a spatial and chronological classification of mass-movement events to gather information on the northward migration and east-west modifications to the path of the Benguela Current.

\section{Oceanographic Setting}

The Benguela Current is a major component in the southwestern Atlantic current system (Figure la). The Benguela Current is a shallow ( $<80 \mathrm{~m} ;<260 \mathrm{ft}$ ), cool, surface current running northward, parallel to the coast, about $180 \mathrm{~km}$ (112 mi) offshore (e.g., Stramma and Peterson, 1989). Near $28^{\circ} \mathrm{S}$, the Benguela Current splits to form the Benguela Ocean Current and the Benguela Coastal Current. The Benguela Coastal Current transports cold water northward from the winddominated coastal area, whereas the Benguela Ocean Current transports warmer water toward the northwest (e.g., Stramma and Peterson, 1989). In combination with the southeastern trade winds, the northwestflowing Benguela Current results in one of the world's major upwelling regions. Modern upwelling along the coast of Namibia takes place in a zone less than $100 \mathrm{~km}$ (62 mi) wide, mostly above the $300-\mathrm{m}$ (1000-ft) isobath. Antarctic intermediate water and the Agulhas Current, consisting of warm surface waters from the Indian Ocean, enter the Cape Basin from the south. The polewarddirected North Atlantic deep water and cold Antarctic bottom water enter the Cape Basin as undercurrents.

Prior to ODP Leg 175, the Neogene history of the southwest African upwelling system was mainly derived from cores collected during the Deep Sea Drilling Project (DSDP) Leg 40 and Leg 75 (Bolli et al., 1978). Siesser (1980) dated the onset of modern Benguela Current circulation at $10 \mathrm{Ma}$, associating enhanced productivity with the stepwise increase in organic-carbon accumulation observed at site 532. Diester-Haass et al. (1992) suggested a progressively northward shift of the Benguela Current since the middle Miocene, initiating upwelling in the Walvis ridge area at about $10.5 \mathrm{Ma}$.

Productivity proxies from ODP Leg 175 cores show a dramatic increase in marine productivity at $6.7-6.5 \mathrm{Ma}$ (e.g., Diester-Haass et al., 2001a). This onset of elevated marine productivity under the Benguela Current correlates with similar increases observed in the Pacific and Indian Oceans since the late Miocene, suggesting a reaction to global changes (Diester-Haass et al., 2001a, and references within). Indeed, elevated marine productivity since the late Miocene corresponds to several major paleoclimatic and paleoceanographic changes (Zachos et al., 2001, and references within): ice caps expanded at both poles, the Isthmus of Panama gradually uplifted and closed, and the North Atlantic deepwater formation started and began to dominate global deep circulation. The onset of Antarctic bottom water took place in the Oligocene, when Drake Passage opened between South America and Antarctica, and Australia and Antarctica separated (e.g., Mackensen and Ehrmann, 1992). This resulted in the formation of the Antarctic Circumpolar Current and thermal isolation of Antarctica (Zachos et al., 2001, and references within).

\section{Geological and Geophysical Setting}

About 3.4 s two-way traveltime (TWT) sediments have been deposited in the southern Cape Basin since its opening between anomalies M9 (126 Ma) and M4 (123 Ma) (Dingle and Robson, 1992). Dingle and Robson (1992) classify four main steps in the development 
of the continental slope and rise: From Aptian to Cenomanian time, the shelf strongly prograded, but during the Cenomanian-Maastrichtian, aggradation prevailed. In the Maastrichtian-early Paleocene, sediment supply decreased because of a shift in the position of the Orange River estuary from $28^{\circ} \mathrm{S}$ to $31^{\circ} \mathrm{S}$, with low sedimentation rates continuing into the Paleogene. Siesser (1980) suggests that in the Cretaceous, the sediment load was transported south, whereas the initiation of the Benguela Current led to northward transport. Depocenters moved toward the continental slope during the Paleogene.

\section{DATA AND PROCESSING}

\section{Reflection Seismic Data}

A grid of 11 high-resolution multichannel seismic reflection profiles with a total length of $1200 \mathrm{~km}$ (750 mi) was gathered in the middle and southern Cape Basin (Bleil et al., 1996) (Figure 1b). The seismic lines cover the location of the ODP drill sites and thus enable correlation with core and log studies. The seismic source was a GI-Gun of $150 \mathrm{in.}^{3}\left(2460 \mathrm{~cm}^{3}\right)$ total volume with a generator volume of $45 \mathrm{in.}^{3}\left(740 \mathrm{~cm}^{3}\right)$, generating frequencies as much as $250 \mathrm{~Hz}$. This theoretically results in a vertical resolution of $3 \mathrm{~m}(10 \mathrm{ft})$ at the seafloor. The data were recorded using a streamer of $600 \mathrm{~m}(1970 \mathrm{ft})$ active length with 24 channels. The shot distance amounted to $25 \mathrm{~m}(80 \mathrm{ft})$, and the sampling rate was $1 \mathrm{~ms}$.

Processing of the multichannel seismic data comprised demultiplexing, definition of the geometry in correspondence to the navigation data (common depth point [CDP] interval, $25 \mathrm{~m}$ [80 ft]), and CDP sorting. No deconvolution was applied because of a very good seismic signal resulting from a short double pulse gained by the inset of the GI-Gun. Further, we refrained from a removal of ocean-bottom multiples because they do not interfere with the signal in the interpreted time range close to the drill sites. A detailed velocity analysis (every 50 CDP) was carried out. Stacking was applied to the data after correcting for spherical divergence losses and normal move-out, and finally, we performed a finite-difference time migration. For display, the data were filtered with a bandpass from 20 to $300 \mathrm{~Hz}$, and no gain was applied. The signal energy was sufficient to image most of the sedimentary column down to reflector AII (late Aptian age, Bolli et al., 1978). The signal spectrum of the processed lines shows a maxi- mum amplitude at a frequency of $75 \mathrm{~Hz}$ in the depth range of the drilling sites. With an average P-wave velocity of $1.5-2 \mathrm{~km} / \mathrm{s}(1-1.2 \mathrm{mi} / \mathrm{s})$ in the upper $600 \mathrm{~m}$ (1960 ft) of sediments, this implies a vertical resolution of about $10 \mathrm{~m}(33 \mathrm{ft})$.

\section{ODP Leg 175 Data}

As part of ODP Leg 175, three sites (sites 1085, 1086, 1087) were drilled in the southern part of the Cape Basin (Figure 1b) (Wefer et al., 1998). ODP site 1085 (hole A, $29^{\circ} 22.4465^{\prime} \mathrm{S}, 13^{\circ} 59.4064^{\prime} \mathrm{E}$ ) is located near the mouth of the Orange River in the Cape Basin in a water depth of $1713 \mathrm{~m}(5620 \mathrm{ft})$ (Figure 1b). With a maximum depth of $605 \mathrm{~m}(1985 \mathrm{ft})$ below seafloor, the site samples the period from Holocene to middle Miocene (0-15 Ma). Sites 1086 (hole A, $31^{\circ} 33.1608^{\prime} \mathrm{S}$, $15^{\circ} 39.6235^{\prime} \mathrm{E}$ ) and 1087 (hole C, 31 ${ }^{\circ} 27.9137^{\prime} \mathrm{S}, 1^{\circ}$ $18.6541^{\prime} \mathrm{E}$ ) are located in the southernmost Cape Basin in about 780 and $1372 \mathrm{~m}$ (2560 and $4501 \mathrm{ft}$ ) of water, respectively (Figure $1 \mathrm{~b}$ ). Site 1086, cored to a maximum depth of $212 \mathrm{~m}$ (696 ft) below seafloor, recovered sedimentary information from the lower Pleistocene to the upper Miocene (1.5-7.5 Ma). The sedimentary section at site 1087 , with a maximum depth of $492 \mathrm{~m}(1614 \mathrm{ft})$ below seafloor, spans the last $11.8 \mathrm{Ma}$.

All three sites in general show a pelagic sediment composition with a hemipelagic portion that most likely comes from the Orange River (Wefer et al., 1998). Sediments are typically classified as foraminifer-rich nannofossil ooze with variations in clay, diatom, and foraminifer content. Carbonate content is high, as is typical for pelagic deposits, whereas organic-carbon content is modest. Sedimentation rates range between 2 and $6 \mathrm{~cm} / \mathrm{k} . y$. (0.8 and 2.4 in./k.y.), about twice the rate of pelagic deep-sea calcareous ooze accumulation (Wefer et al., 1998).

Figure 2 shows a selection of core-log and downhole-logging parameters used for a correlation of core and seismic data. Calcium carbonate $\left(\mathrm{CaCO}_{3}\right)$ and total organic-carbon (TOC) distribution, as well as diatom and silica abundance, were selected as characteristic sedimentological parameters with a marker role in reconstruction of productivity and upwelling. Grainsize variations are supposed to have a direct influence on impedance contrast, and sedimentation rates are expected to be mirrored in the pattern of seismic reflections. The core and downhole-logging data were edited to get rid of faulty values. For some parameters, improved data sets were available, which we included. 
To obtain data logs over the entire core/hole length for some parameters, we joined samples from different data sets (Figure 2a, c). Where available, we preferred downhole-logging data, especially for P-wave velocity and density. These values were selected when caliper records showed a reasonable hole diameter; otherwise, samples originate from core data. No depth correction for core expansion was applied to the core samples, because a comparison of core and downhole measurements of natural gamma-ray intensity allowed a detailed correlation (Figure 2a).

\section{Correlations of Site and Seismic Data}

To enable an assignment of site data to seismic reflectors, the P-wave velocity logs were used to convert the data from the depth domain to the two-way traveltime domain (Figure 2). Acoustic impedance and reflection coefficients were calculated in combination with the density and velocity logs. Synthetic seismograms were generated by convolution with a $75-\mathrm{Hz}$ Ricker wavelet, according to the maximum of signal spectrum (Figure 2).

A depth-age conversion was applied using the shipboard biostratigraphic and magnetostratigraphic summaries (Wefer et al., 1998) and revisions where available (Giraudeau et al., 2001b; Berger and Wefer, 2002). Thus, ages were assigned directly to those reflectors within the depth span of the single sites (Figure 2). For lower units, which are out of this depth range, we refer to the results of DSDP Sites 360 and 361 (Bolli et al., 1978) and the KUDU boreholes (McMillan, 1990).

\section{RESULTS}

\section{Seismic Stratigraphy}

The sedimentary sequence in the upper 1.5-s TWT was divided into seismic units based on their internal reflection pattern and the nature of cycle termination. The units were denoted southern Cape Basin (SCB)-1 to SCB-4, from top to bottom. The corresponding base reflectors are named SCB-A to SCB-D (Figure 2). A compilation of the stratigraphy is listed in Table 1.

\section{Unit SCB-1}

The uppermost unit, SCB-1, consists of a sequence of two to four continuous, high-amplitude reflectors, running parallel to the seafloor, with a thickness of $80 \mathrm{~ms}$ TWT ( $65 \mathrm{~m} ; 210 \mathrm{ft}$ ) at site 1085 (Figure 2a; Table 1). In between the strong-amplitude reflectors, internal reflectors can be identified in parts, indicating additional layers (e.g., Figure 2a, CDPs 6000-6200). Incisions interrupt the seafloor, indicating mass movements (e.g., Figure 2a, CDP 5800) or channels. The base of unit SCB-A is formed by a discontinuity truncating the layers below. Referring to ODP Leg 175 age-depth relations, we assign an age of $1.5 \mathrm{Ma}$ to interface SCB-A at site 1085 and $1.9 \mathrm{Ma}$ at site 1087 .

The strong amplitudes and low frequencies in SCB1 are probably generated by wave interference between closely spaced reflectors. Additionally, high amplitudes are indicative of a high impedance contrast, i.e., variations in P-wave velocity and density. Support for this interpretation is given by the core data where strong changes in velocity and density are abundant in the upper $70 \mathrm{~m} \mathrm{(230} \mathrm{ft)} \mathrm{below} \mathrm{seafloor} \mathrm{(Figure} \mathrm{2).} \mathrm{These} \mathrm{var-}$ iations are the origin of the packed, strong-amplitude reflections observed in the respective synthetic seismograms. We consider two possibilities influencing density and velocity at the sites: (1) grain-size variability and/or (2) fluctuations in carbonate content.

\section{Grain-Size Variability}

The grain-size distribution was studied in detail at site 1086 (Berger and Wefer, 2002). A high sand content in the uppermost cores suggests winnowing, and a hiatus comprises most of the Brunhes Chron (0-0.7 Ma). The discrete velocities reveal relatively high values (1600$1700 \mathrm{~m} / \mathrm{s} ; 5250-5580 \mathrm{ft} / \mathrm{s}$ ) in the upper portion (Figure $2 \mathrm{~b}$ ) decreasing with depth, which may be caused by the concentration of coarser grained particles. No further studies on the coarse fraction in the uppermost core sections besides the shipboard descriptions are available for sites 1085 and 1087. Foraminifera, however, are the main component of the sand fraction and can thus be used as a grain-size indicator. Sediments of all three sites show a high foraminiferal portion in the upper section, decreasing with depth (Wefer et al., 1998). At site 1087, sandy nannofossil-foraminifer ooze is present in 50-100-cm (20-40-in.)-thick beds in the upper $45 \mathrm{~m}$ (148ft) below seafloor. The beds generally have a sharp base and grade upward from foraminifer sands into more clay-rich foraminifer-nannofossil ooze. The beds are interpreted as turbidites or, as at site 1086, the product of winnowing (Wefer et al., 1998). At site 1085, foraminifera are abundant in lithological subunit IA (0-90 m [0-200 ft] below seafloor) and decrease from abundant to sparse below. Studies on the 


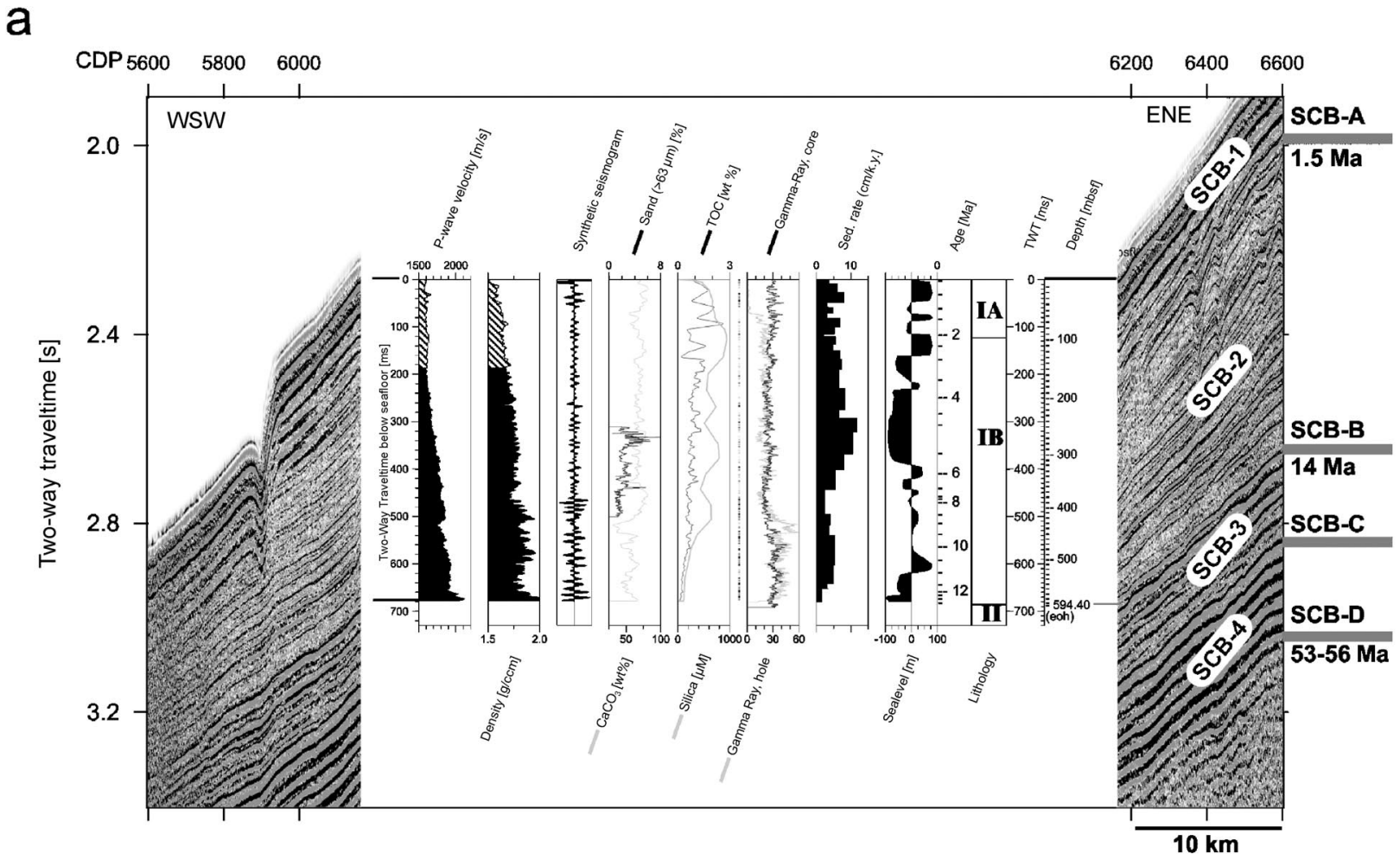

b

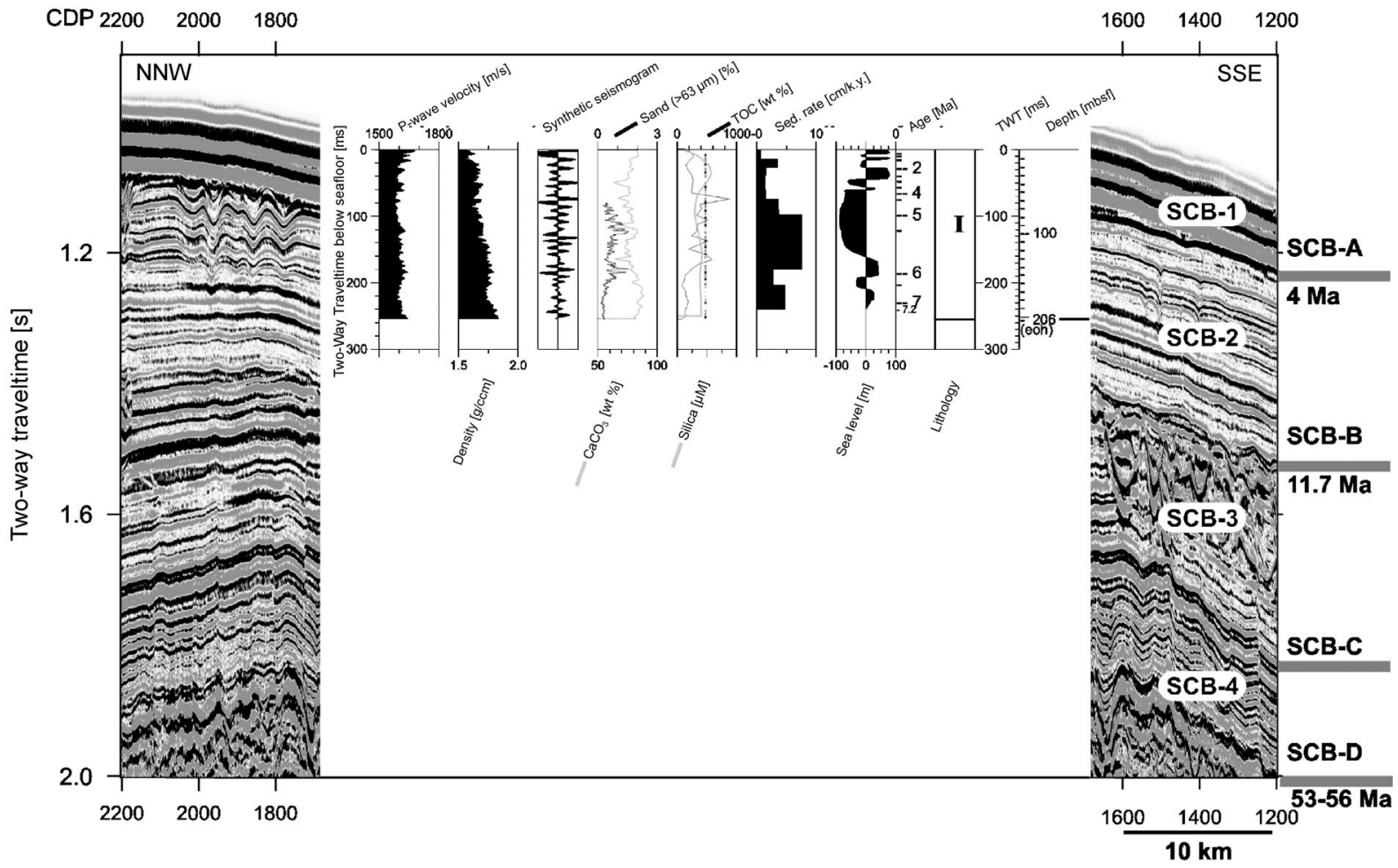

Figure 2. Compilation of drill-site data sampled in two-way traveltime (ms) and parts of the seismic lines: AWI-96009 and site 1985 (a), AWI-96006 and site 1086 (b), and AWI-96008 and site 1087 (c). See Figure 1b for locations. Seismic units are denoted by SCB-1 to SCB-4, whereas gray bars mark the seismic reflectors SCB-A to SCB-D and their age. Reflector SCB-D corresponds to reflector D of Emery et al. (1975). P-wave velocity logs and density logs are composed of discrete values (hatched) and downhole logging data (black) for sites 1085 (a) and 1087 (c). Coarse fraction data origin are from L. Diester-Haass, P. A. Meyers, and T. Bickert (2004, personal communication). 


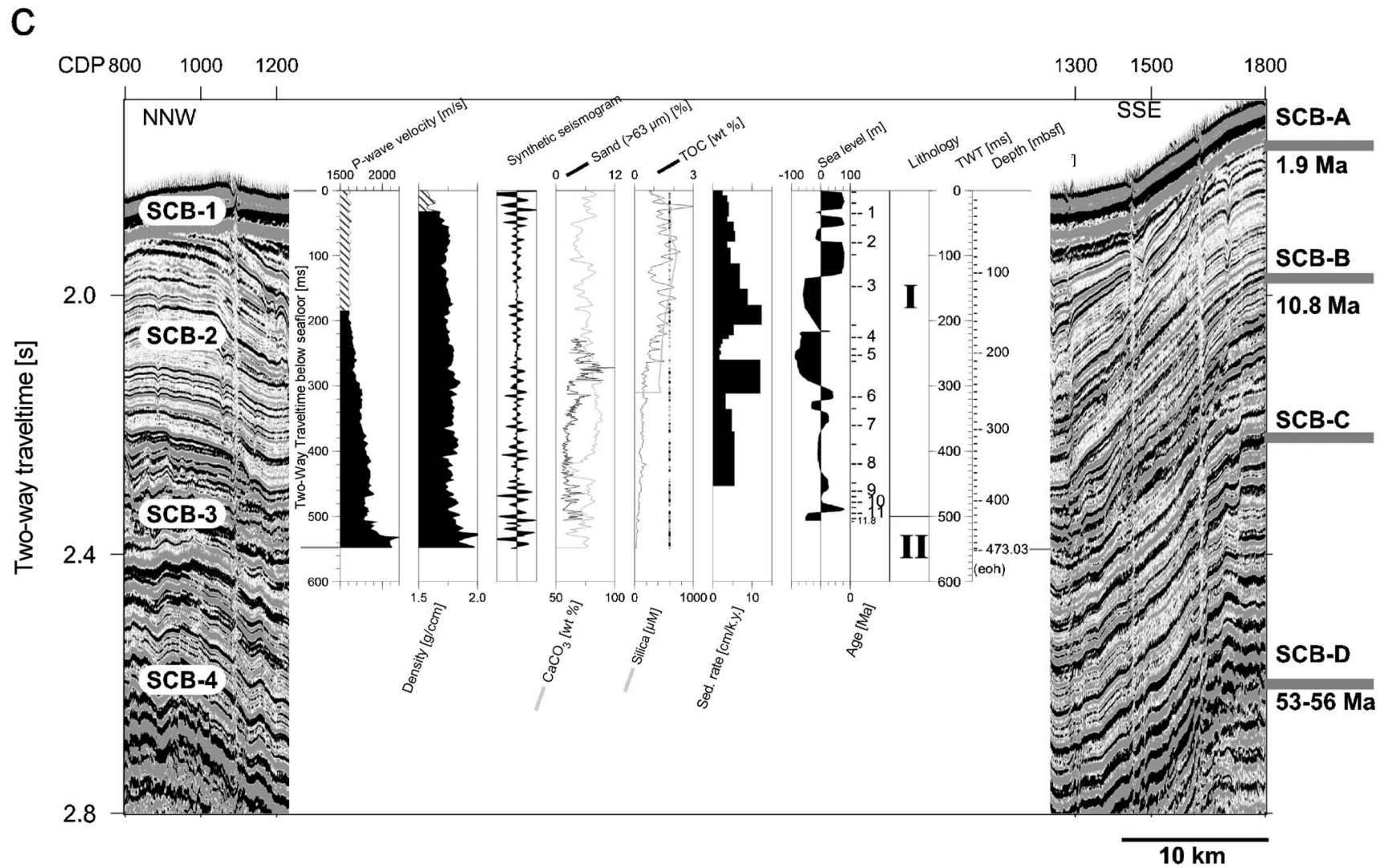

Figure 2. Continued

abundance of foraminifera in the Cape Basin suggest that the assemblages roughly follow glacial-interglacial cycles, suggesting cyclicity in upwelling strength and the width of the associated belt of upwelled water, in response to global climate cycles (e.g., Giraudeau et al., 2001a).

\section{Carbon Content Fluctuations}

Calcium carbonate content and carbon concentrations were studied at all three sites. The fluctuations in $\mathrm{CaCO}_{3}$ content and $\mathrm{TOC}$ concentration are strongest in the upper $50 \mathrm{~m}(160 \mathrm{ft}$ ) below seafloor (Figure 2a-c) and indicate enhanced production and maximum amplitude variations during the last 1.25 m.y. (Meyers, 2001; Giraudeau et al., 2001b). The variations in TOC concentration probably result from downslope transport of organic-rich sediments from the shelf edge that is related to glacial-interglacial variations in trade-wind activity and in sea level (Diester-Haass et al., 1992; Meyers, 2001; Giraudeau et al., 2001b).

We interpret the seismic unit SCB-1 to document glacial-interglacial cycles, although we cannot resolve individual reflectors for each cycle. High-amplitude re- flectors are likely to indicate variations in depositional environment, which find their expression in fluctuations of foraminifera preserved in the coarse fraction. The date of about 1.4-1.9 Ma argues for depositional changes corresponding to glacial-interglacial cycles that intensified in the Pleistocene, or to a sudden-onset period of sea level changes since the early Pliocene. Additionally, incursions of warm Agulhas waters may have caused changes in the depositional environment, as shown by studies on site 1086 material (Berger and Wefer, 2002).

\section{Unit SCB-2}

Unit SCB-2 is characterized by weak reflection amplitudes and continuous layering. Its thickness amounts to about $530 \mathrm{~m}(1740 \mathrm{ft}$ ) at site 1085 (Figure 2a, 2.352.98 s TWT; Table 1) and decreases to $250-400 \mathrm{~m}$ $(820-1310 \mathrm{ft})$ in the south at sites 1086 and 1087 (Figure $2 \mathrm{~b}, \mathrm{c})$. Numerous slumping features are concentrated along the middle and upper shelf slope (e.g., Figure 3a). Toward the shelf break, the reflectors show a toplap termination, indicating nondeposition of this 
Table 1. Compilation of Defined Seismic Stratigraphy

\begin{tabular}{|c|c|c|c|c|c|c|c|}
\hline \multirow{2}{*}{$\begin{array}{l}\text { Seismic } \\
\text { Unit }\end{array}$} & \multirow[b]{2}{*}{ Seismic Character } & \multirow[b]{2}{*}{ Interpretation } & & \multicolumn{3}{|c|}{ Site } & \multirow{2}{*}{$\begin{array}{l}\text { Base } \\
\text { reflector }\end{array}$} \\
\hline & & & & 1085 & 1086 & 1087 & \\
\hline \multirow[t]{3}{*}{ SCB-1 } & \multirow{3}{*}{$\begin{array}{l}\text { two to three continuous, } \\
\text { high-amplitude, low- } \\
\text { frequency reflectors, } \\
\text { parallel to seafloor, } \\
\text { incisions at seafloor }\end{array}$} & \multirow{3}{*}{$\begin{array}{l}\text { interferences of reflections } \\
\text { of closely spaced layers; } \\
\text { high impedance contrast } \\
\text { may relate to grain-size } \\
\text { variations in the deposits } \\
\text { fluctuating with glacial- } \\
\text { interglacial cycles }\end{array}$} & thickness [ms] & 80 & 75 & 75 & \multirow[t]{3}{*}{ SCB-A } \\
\hline & & & thickness [m] & 64 & 60 & 60 & \\
\hline & & & age [Ma] & 1.5 & 4.3 & 1.9 & \\
\hline \multirow[t]{3}{*}{ SCB-2 } & \multirow{3}{*}{$\begin{array}{l}\text { continuous, closely } \\
\text { spaced low-amplitude } \\
\text { reflectors, toplap below } \\
\text { shelf break, disturbed } \\
\text { by slumping features }\end{array}$} & \multirow{3}{*}{$\begin{array}{l}\text { low impedance contrast } \\
\text { indicates homogenous } \\
\text { lithology as caused by } \\
\text { pelagic sedimentation; } \\
\text { slumps indicate high } \\
\text { instability of deposited } \\
\text { material; unit is associated } \\
\text { with the establishment } \\
\text { of the upwelling system }\end{array}$} & thickness [ms] & 620 & 320 & 445 & \multirow[t]{3}{*}{ SCB-B } \\
\hline & & & thickness [m] & 530 & 264 & 380 & \\
\hline & & & age [Ma] & 14 & $11.7^{*}$ & $9.5-11.8^{*}$ & \\
\hline \multirow[t]{3}{*}{ SCB-3 } & \multirow{3}{*}{$\begin{array}{l}\text { continuous moderate- } \\
\text { to strong-amplitude } \\
\text { reflectors, minor } \\
\text { vertical faults, onlaps } \\
\text { on paleoshelf structure }\end{array}$} & higher impedance contrast & thickness [ms] & 155 & 216 & 330 & \multirow[t]{3}{*}{ SCB-C } \\
\hline & & caused by increasing & thickness [m] & 140 & 195 & 310 & \\
\hline & & $\begin{array}{l}\text { lithification and fluctuation } \\
\text { in carbonate content; } \\
\text { vertical faults caused } \\
\text { by differential compaction; } \\
\text { unit represents shelf break- } \\
\text { eroded material deposited } \\
\text { during a major Oligocene- } \\
\text { Miocene regression }\end{array}$ & age [Ma] & - & - & - & \\
\hline \multirow[t]{3}{*}{ SCB-4 } & \multirow{3}{*}{$\begin{array}{l}\text { sequence of strong- } \\
\text { amplitude, low- } \\
\text { frequency reflectors, } \\
\text { vertical faults }\end{array}$} & \multirow[b]{3}{*}{$\begin{array}{l}\text { higher impedance contrast } \\
\text { caused by increasing } \\
\text { lithification and fluctuation } \\
\text { in carbonate content; } \\
\text { vertical faults caused by } \\
\text { differential compaction; } \\
\text { unit represents shelf } \\
\text { break-eroded material } \\
\text { deposited during a major } \\
\text { Oligocene-Miocene } \\
\text { regression }\end{array}$} & thickness [ms] & 170 & 284 & 135 & \multirow[t]{3}{*}{ SCB-D** } \\
\hline & & & thickness [m] & 160 & 285 & 135 & \\
\hline & & & age [Ma] & $53-56$ & $53-56$ & $53-56$ & \\
\hline
\end{tabular}

*Age is extrapolated from sedimentation rates and thickness.

**Age is taken from the KUDU drill site data (McMillan, 1990) and from DSDP Leg 40 sites 360 and 361 (Bolli et al., 1978).

unit on the shelf. At its base, unit SCB-2 lies unconformable on unit SCB-3 (e.g., Figure 4b, CDPs 4500 and 5900). The surface of this interface, named here SCB$\mathrm{B}$, is undulatory and disrupted by sliding and slumping features and minor faults (e.g., Figure 4b, CDP 4090 and 4850).

The depth of reflector SCB-B is close to the base of site 1085 (2.982 s TWT, $606 \mathrm{~m}[1988 \mathrm{ft}]$ below 
a

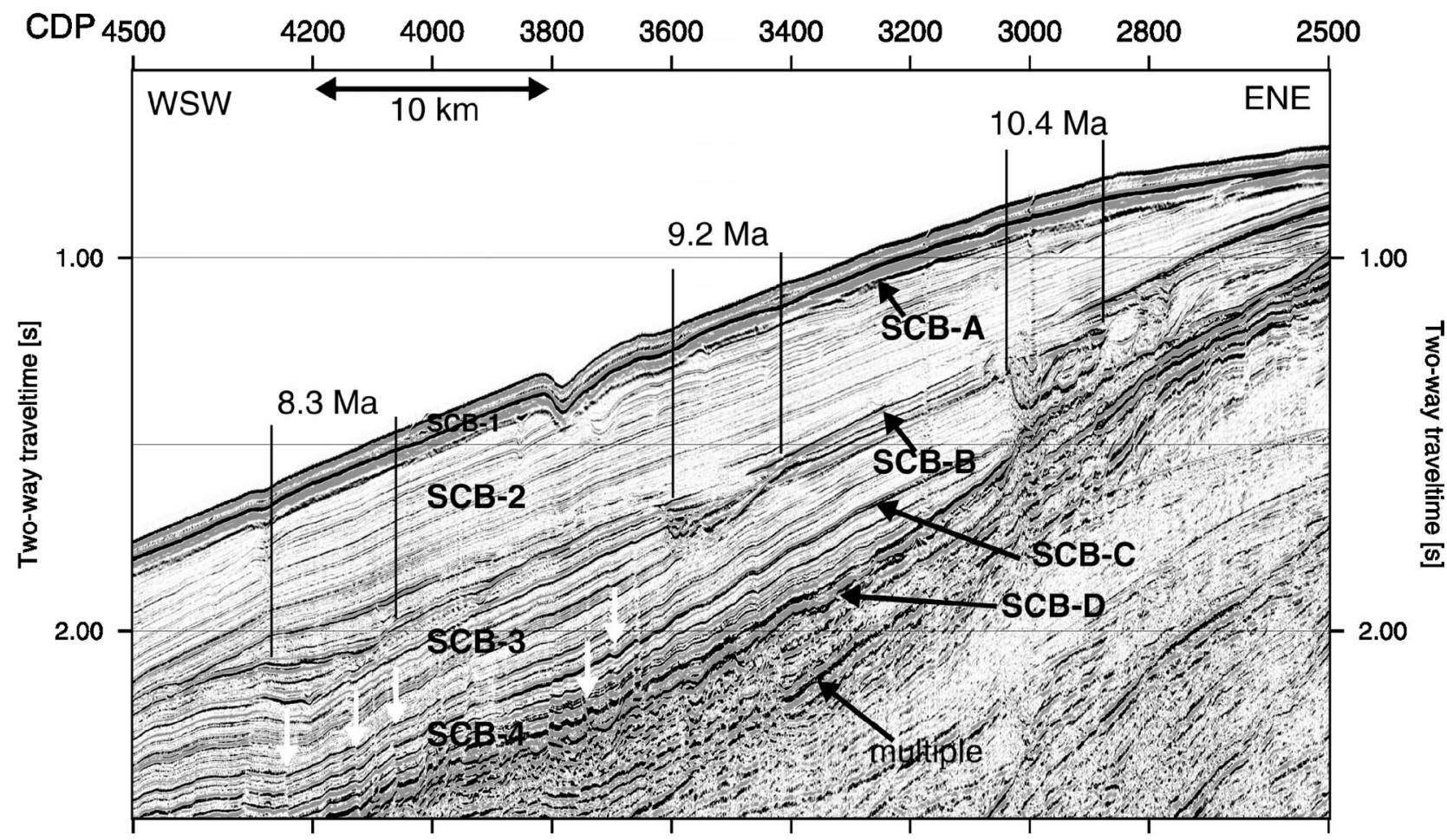

b

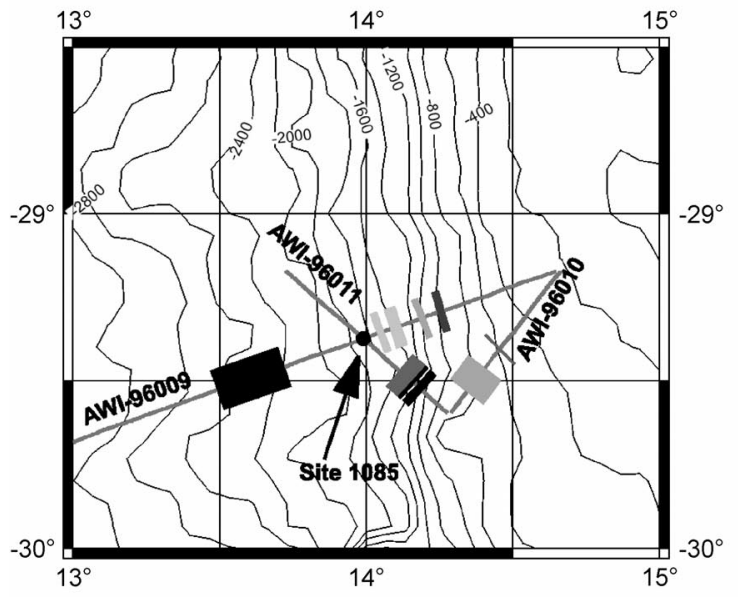

C

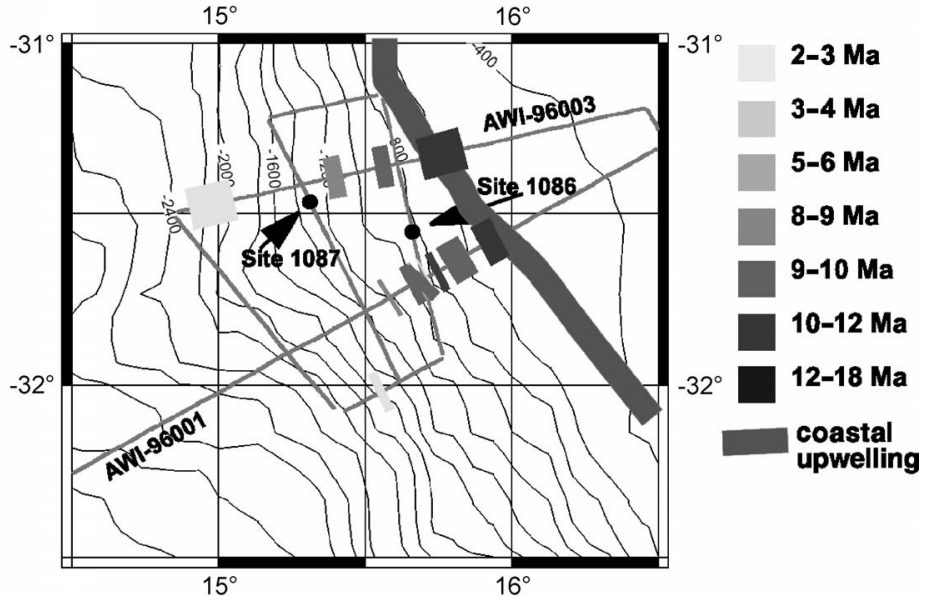

Figure 3. Enlarged section of line AWI-96003 showing examples of mass movements (a). A minimum age for the slumping events was estimated from the age of the first continuous layer covering the trough formed by a slump. The locations of the scarps seem to move seaward with decreasing age of the slumping events. White arrows show examples for minor vertical faults disrupting the seismic units SCB-3 and SCB-4. Distribution of the slumping locations on the northern lines (b) and southern lines (c). The different shades of gray mark the age of the events, starting with light gray for 2-3 Ma to black for 12-18 Ma. The southern lines (c) show the westward shift of the scarps with decreasing age very well. The seaward boundary of the modern coastal upwelling region (after Lutjeharms and Stockton, 1987) is marked with a gray line. Note that the locations of the slide scarps are outside the upwelling region (c).

seafloor) and the boundary between lithostratigraphic units I and II. This interface is formed by a contact between nannofossil ooze and microfaulted clay-rich nannofossil ooze (Wefer et al., 1998). Unfortunately, at site 1085, no velocity, density, or grain-size values are available for this depth range to link lithology 
a

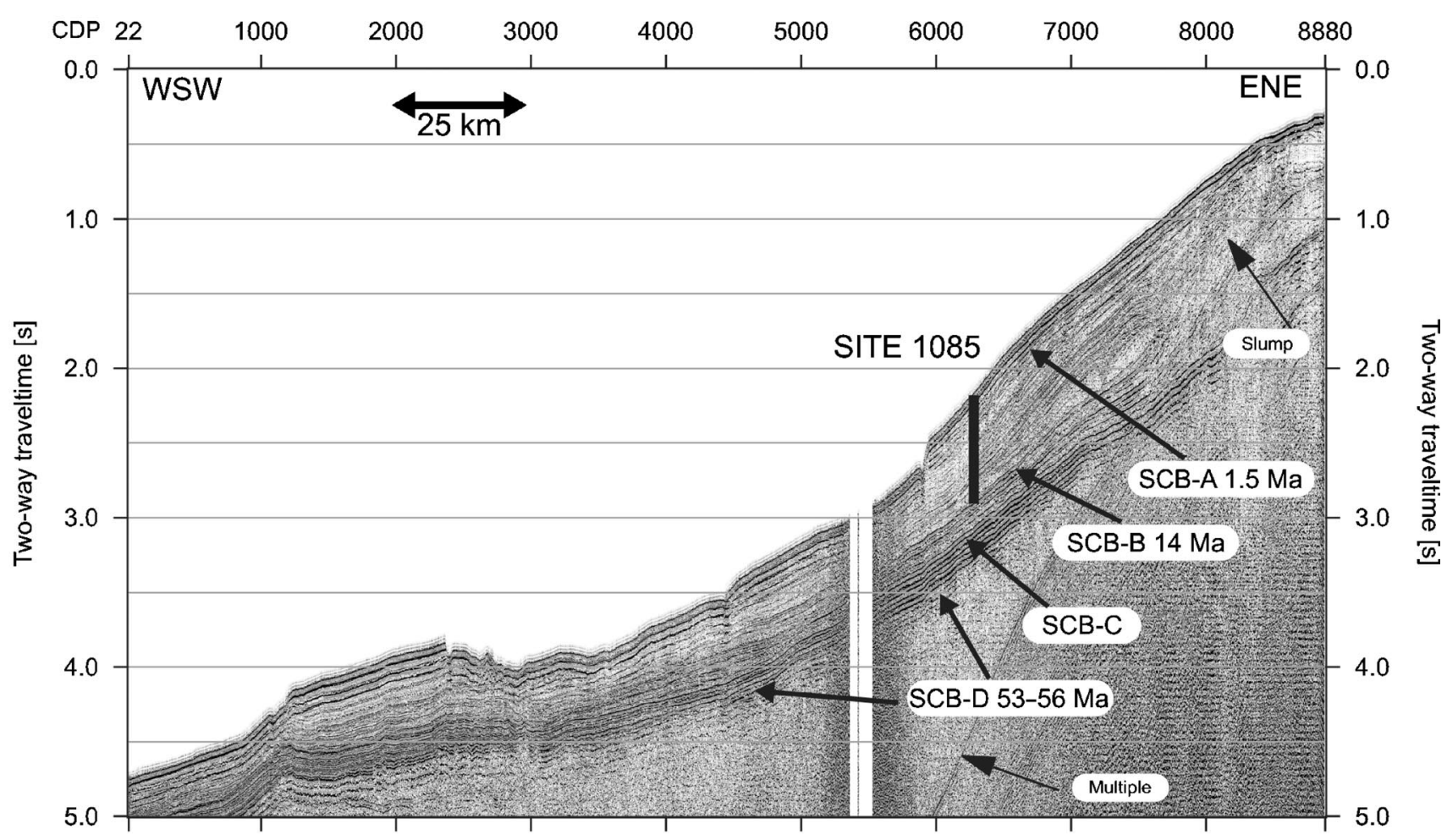

b

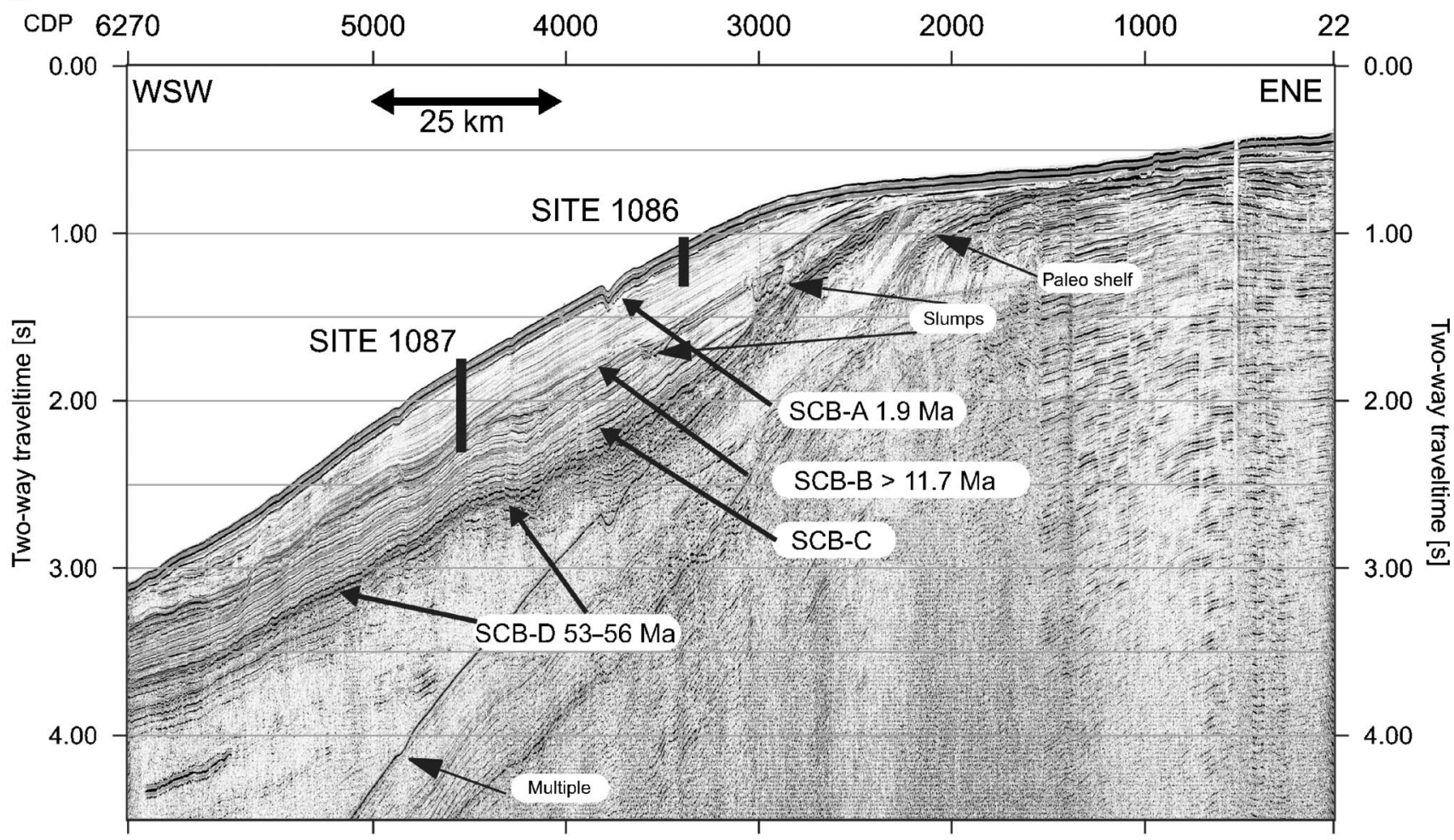

Figure 4. Seismic lines AWI- 96009 (a) and AWI-96003 (b) (location in Figure 1b) showing the defined seismic stratigraphy. Black bars mark location and penetration depth of the ODP coring. Sites 1086 and 1087 are projected onto line AWI-96003 (b) to highlight similarities and differences in stratigraphy of the northern and southern locations. Some examples of slumping events are noted. 
directly to the reflector SCB-B and the layers below. Nevertheless, we regard this reflector as the expression of the interface between the lithological units. Correlating with ODP Leg 175 age-depth relations, we assign an age of $14 \mathrm{Ma}$ to SCB-B (Figure 2a). At site 1086, drilling did not reach horizon SCB-B. We assign an age of $11.7 \mathrm{Ma}$ to the interface based on extrapolation, using thickness and averaged sedimentation rate in SCB-2 (Figure 2b; Table 1). At site 1087, reflector SCB-B corresponds to the boundary between lithostratigraphic units I and II (Figure 2c). Age models differ from 11.8 Ma (Giraudeau et al., 1998) to $9.5 \mathrm{Ma}$ (Berger and Wefer, 2002) for this interface. These data probably represent only a minimum age for this boundary because numerous slumping and gliding features evident in the seismic lines (see above) indicate disarrangement and a lack of deposits. According to this, core data show at least three discontinuities below $425 \mathrm{~m}$ (1394 ft) below seafloor at site 1087 (Wefer et al., 1998). Thus, we propose a synchronous buildup of unit SCB-2 since about 14 Ma for the whole Cape Basin.

The weak amplitudes and continuous reflectors dominating unit SCB-2 are indications of a more homogenous lithology, likely because of pelagic deposition of clay and ooze (Sangree and Widmier, 1979). This facies interpretation is confirmed by the results of sites 1085-1087, which reveal sediments with a high carbonate content, consisting predominantly of foraminifer-nannofossil ooze and nannofossil ooze (Wefer et al., 1998).

The observed decrease in thickness of unit SCB-2 from north to south indicates a higher input of sediments in the north of the region and/or (more likely) intense erosion influencing the southern areas. Enhanced upwelling in the north, inducing greater productivity and deposition, could be the reason for the observed thickening of unit SCB-2 at site 1085. This notion is supported by studies on organic-carbon concentrations that reveal a higher deposition/productivity rate in the north (Meyers and Robinson, 2001). Because of the middle to upper Miocene aridification of the $\mathrm{Na}$ mibian landmass (10-11 Ma) and accompanying reduction in riverine terrigenous input (e.g., Siesser 1980), we do not believe the Orange River input is a main reason for the thicker northern SCB-2. We suggest that a higher erosional influence in the south is the most plausible reason for the observed differences in thickness. Slumping features seem to be of larger scale on the southern seismic profiles, and interface SCB-B shows the character of a large gliding plane on these sections (e.g., Figure 4b, CDPs 3000-6000).
We consider three possibilities for the development of unit SCB-2: (1) continental uplift, (2) sea level rise, and (3) climate changes.

\section{Continental Uplift}

Southern Africa underwent significant uplift during the Cenozoic. During the middle Miocene (16-10 Ma), there was asymmetrical uplift, tilting the African continent toward the west with an amplitude of 150$300 \mathrm{~m}$ (490-980 ft) (Partridge and Maud, 1987). Intense erosion and a significant increased input in terrigenous matter would be the likely results of this uplift, and hence, we would expect to observe a prograding development of the southwest African margin. In contrast, relatively little terrigenous material and predominantly marine organic matter are found at the three ODP sites (Meyers, 2001; Wefer et al., 1998). The KUDU drilling sites also reveal the great majority of early Miocene sediments to be biogenic, originating from the middle or outer shelf (McMillan, 1990). Thus, we do not consider unit SCB-2 to be a main result of continental uplift.

\section{Sea Level Rise}

A major Neogene transgression began in the middle Miocene and probably reached its greatest extent in the late Miocene or early Pliocene (Siesser and Dingle, 1981). This relative rise in sea level could explain the pelagic deposits of unit SCB-2 as well its prograding shape. Brief regressive pulses (e.g., near the MiocenePliocene boundary) may have triggered the mass movements observed in SCB-2 because of instability of slope sediments.

\section{Climate Changes}

The development of SCB-2 correlates with a rapid enlargement of the Antarctic ice sheet during the middle Miocene ( $13 \mathrm{Ma}$, Zachos et al., 2001, and references within). As a consequence, intensified trade winds caused the corresponding southwest African upwelling regime to develop during the Neogene (Berger and Wefer, 2002, and references within). This led to increased production and consequently higher deposition. Palaeontological and geochemical investigations from DSDP Site 362 reveal the onset of upwelling at about $10 \mathrm{Ma}$ near the Walvis ridge (Siesser, 1980).

It is noteworthy that the major increase in upwelling productivity since late Miocene (6.7-6.5 Ma), as proposed in numerous studies (e.g., Diester-Haass et al., 2001a; Meyers, 2001), is not seen in the seismic reflection pattern of SCB-2 (Figure 2). Peaks and 
fluctuations in carbon and carbonate accumulation in Pliocene-Pleistocene sediments (Giraudeau et al., 2001b) do not cause any significant changes in $\mathrm{P}$-wave velocity and/or density and are consequently not evident in the seismic sections. We suggest that our minimum determined age of $14 \mathrm{Ma}$ for unit SCB-2 marks an earlier commencement of the upwelling-enhanced productivity regime in the Cape Basin. A further intensification in upwelling, like that in the late Miocene, did not cause any impedance contrast resolvable by our data. Berger and Wefer (2002) do not preclude a gradual enhancement of production from the middle Miocene ( $14 \mathrm{Ma}$ ) into the late Miocene. However, mass movements can disrupt the records of carbon deposition and give rise to an apparently heterogeneous pattern of biogenic production (Giraudeau et al., 2001b). Our conclusion is supported by this suggestion as we observe numerous slumps in SCB-2.

\section{Unit SCB-3}

Seismic unit SCB-3, with a thickness of about $140 \mathrm{~m}$ (460 ft) at site 1085 (Figure 2a, 2.98-3.14 s TWT; Table 1), is composed of numerous, closely spaced, continuous reflectors of moderate to strong amplitude. Seaward, the layers merge to a smaller number of highamplitude, low-frequency reflectors (Figure 4a, CDP 3000). Like those in unit SCB-2, the layers of unit SCB3 show toplap to unit SCB-1 below the shelf, indicating nondeposition (Figure 4b, CDP 2450). The morphology of the top of the unit is significantly disturbed by slumping features and slide scarps that concentrate along the upper slope (e.g., Figures 3a, 4b, CDPs $2800-$ $3100,3400-3600,4100-4300$ ). An increase in smallscale faults disrupting the layers is observed with depth (Figure 3a). The base of unit SCB-3 is formed by a strong and continuous reflector, $\mathrm{SCB}-\mathrm{C}$, which onlaps on unit SCB-4 below the shelf break (Figure 4b, CDP 25003000). An interpretation and age estimation of unit SCB-3 is given together with unit SCB-4 because of their similar reflection pattern.

\section{Unit SCB-4}

Unit SCB-4 is represented by a sequence of highamplitude reflectors with a thickness of $160 \mathrm{~m}(525 \mathrm{ft})$ at site 1085 (Figure 2a; Table 1). The thickness increases slightly toward the shelf, before ending in a wedge below the shelf break (Figure 4b, CDP 3000). Amplitudes increase with depth, as do the vertical displacements of reflector segments because of numerous normal faults.

We defined the base of unit SCB-4 to be the lowest and strongest of a band of high-amplitude reflectors, named here SCB-D. Below unit SCB-4, the seismic reflection pattern changes to a transparent style with low-amplitude, low-frequency reflectors and only some fragmentary, higher amplitude reflectors (Figure $4 \mathrm{~b}$, CDPs 5600-6200, 4.25 s TWT). The band of highamplitude reflectors, including SCB-D, can be found all over the Cape Basin on other seismic lines (e.g., Emery et al., 1975; Austin and Uchupi, 1982; Brown et al., 1995) and has been described as reflector D (Uchupi and Emery, 1972) or L (Gerrard and Smith, 1982). Bolli et al. (1978) dated D at DSDP Site 361 as PaleoceneEocene ( $53 \mathrm{Ma}$ ); Gerrard and Smith (1982) suggest that horizon L marks the base of the Eocene ( $\sim 56 \mathrm{Ma})$ near the outer shelf and the base of the Tertiary ( $65 \mathrm{Ma})$ close to the coast. Because the locations of these former investigations are close to our observed area (e.g., KUDU drill sites are only $65 \mathrm{~km}$ [40 mi] distant from line AWI-96009 (Figure 1b), and the seismic lines reveal a similar reflection pattern and depth, we correlate SCB-D with reflector $\mathrm{D} / \mathrm{L}$. With these constraints, we estimate a sedimentation rate for units SCB-3 and SCB-4. The sedimentary sequence below the drill location of site 1085 appears to be undisturbed and complete (Figure 4a). With a thickness of about $300 \mathrm{~m}(1000 \mathrm{ft})$ (Table 1), we determined an average sedimentation rate of $0.7 \mathrm{~cm} / \mathrm{k} . \mathrm{y}$. (0.3 in./k.y.) for both units.

Both units, SCB-3 and SCB-4, consist of continuous reflectors indicating pelagic sedimentation. The strong amplitudes of the reflectors, however, can only result from striking impedance contrasts, i.e., density and P-wave velocity contrasts, in the deposited material. We suggest increasing lithification as the cause of elevated density and velocity values in these units. The small vertical displacements we attribute to differential compaction. Additionally, variations in carbonate content, caused by fluctuations of the carbonate compensate depth (CCD) and dissolution, can influence density and velocity. Indeed, reflector D marks a sharp lithological transition from high carbonate content to pure pelagic clays below and thus is supposed to mark a passage through the Paleocene carbonate dissolution depth (Bolli et al., 1978). The carbonate fluctuations above $D$ are caused by CCD shifts because of incursions of carbonate-rich Antarctic bottom water or sea level variations (Bolli et al., 1978). Another reason for a high impedance contrast can be the input of different material because of erosion caused by sea level 
fluctuations or continental uplift. Relative sea level dropped briefly during the middle Eocene, followed by a major regression during the Oligocene and early Miocene (Siesser and Dingle, 1981). In addition, significant uplift of South Africa occurred during the Cenozoic (e.g., Partridge and Maud, 1987). On the base of KUDU drill site data, McMillan (1990) described major breaks from early Maastrichtian to latest Paleocene, from the earliest early Eocene to the latest late Eocene and also from middle Oligocene to early Miocene over the South African continental shelf. We interpret units SCB-3 and SCB-4, thinning out toward the shelf, to consist of such shelf break-eroded material deposited during the duration of these hiati.

\section{Distribution of Mass Movements}

The seismic profiles show that the southern Cape Basin has been affected by significant mass movements. This is documented by numerous scarps, slumping, and channel forms in the sedimentary layers across the upper-slope environment (e.g., Figure 3a). The scarps are located mainly 200-300 km (120-190 mi) offshore at the upper slope in a water depth of 500-2500 $\mathrm{m}(1600-8200 \mathrm{ft})$, where the slope angle is about $1-$ $1.5^{\circ}$. The scarps show a typical length of between 2 and $5 \mathrm{~km}(1.2$ and $3.1 \mathrm{mi}$ ) and a trough depth (vertical displacement) of 30-100 m (100-330 ft). The features occur exclusively in the upper two units SCB-2 and SCB-1. The infill in most of the troughs reveals continuous, moderate- to high-amplitude reflections that onlap the trough walls. The most interesting phenomenon is that the location of the slide scarps shifts seaward (westward) with decreasing depth and thus with decreasing age (Figure 3b, c).

A minimum age was assigned to the mass-wasting events by determining the age of the oldest continuous layer covering the infill of the scarps' depressions. All scarps observed along the slope are younger than about $14 \mathrm{Ma}$ (middle Miocene), except for one event on line AWI-96009 (Figure 4a, CDPs 4100 and 5050) that is identified with an age of about $18 \mathrm{Ma}$. On the northern lines (Figure $3 \mathrm{~b}$ ), the scarps concentrate in the upper half of unit SCB-2 and at the seafloor. The main occurrence of mass-movement features in the southern lines is in the lower part of unit SCB-2, close to the transition to SCB-3, which gives the interface the character of an extended gliding plane. All lines show an extended scarp feature below the shelf break in unit SCB-2 with a strong presence down to the seismic unit SCB-3 (Figure 4a, CDPs 7600-8600; Figure 3a,
CDPs 2500-3100). In general, unit SCB-3 does not seem to be influenced by slumping events farther downslope.

\section{DISCUSSION}

We consider two reasons for the occurrence of the observed mass movements and their westward shift: (1) erosional influence or (2) instability of the sedimentary column in the upper two units.

Erosion can be related to the effect of bottom currents, triggering slumps and slides directly by physical forces (Tucholke and Embley, 1984). The westward shift of the scarp locations would thus indicate a shift of bottom currents downslope with time. The Antarctic bottom water is a bottom current that strongly influences sedimentation off Namibia (Siesser, 1980). It developed in the late Miocene as a consequence of the rapid enlargement of the middle Miocene Antarctic ice sheet ( $\sim 13 \mathrm{Ma}$, Zachos et al., 2001, and references within). Indeed, this period correlates with the onset of unit SCB-2 and the occurrence of the scarps. Tucholke and Embley (1984) described continuous erosional zones along the perimeter of the Cape Basin but at depths of 4000-5000 $\mathrm{m}(13,000-16,500 \mathrm{ft})$. The scarps in SCB-1 and SCB-2 are probably located too far upslope to be the results of scouring by late Miocene Antarctic bottom water, although we cannot rule out the possibility of undercutting of the lower slope being an interim cause as proposed by Dingle and Robson (1992). We exclude the possibility of erosion by the Benguela Current and the action of Benguela Current upwelling forces on the deposits: the Benguela Current itself is a shallow surface current (Shannon, 1985) and cannot directly influence the seafloor surface. Modern upwelling cells are restricted to shallower water depths along the inner shelf and shelf edge (Stramma and Peterson, 1989). Deeper currents parallel to the shelf, which are strong enough to erode the upper slope, could have developed as a result of increasing activity of intermediate waters in the southern oceans and South Atlantic during the late Oligocene and middle Miocene. One possibility is the North Atlantic deep water, which initiates by cooling in northern latitudes (Greenland Sea) and then flows south (Berger and Wefer, 1996) (Figure la). North Atlantic deep-water circulation is supposed to have started about $10 \mathrm{Ma}$, as seen in a drop of carbonate compensation depth (e.g., Berger and Wefer, 1996). Such a change of oceanic circulation could result in erosion of the upper slope. Antarctic intermediate 
water running northward along the upper shelf slope overlies the North Atlantic deep water above a depth of about $1500 \mathrm{~m}(5000 \mathrm{ft})$ (Figure 1a, sketch). It is also possible that these two countercurrents affect the seafloor along their contact zone and hence trigger mass movements.

Instability in the sedimentary layers as a cause of slumping events is thought to be a result of different factors. A simple explanation is that instability in the deposits is at a maximum on the steepest part of the shelf slope. Consequently, slump locations would concentrate at the upper slope and migrate seaward with progradition of the continental margin. Additionally, epeirogenic uplift of the sediment-loaded margin could have led to successive slope failures during the Tertiary (Dingle and Robson, 1992). Partridge and Maud (1987) proposed intense uplift and westward tilting of the African surface from the middle Miocene to late Pliocene, accompanied by erosion. Instability could also be the result of high deposition rates, and consequently, the shift of scarps could reflect a shift of deposition centers. One reason for a high sedimentation rate could be an enhanced input of terrigenous material, but this is not consistent with middle to upper Miocene (10-11 Ma) aridification of the Namibian hinterland (e.g., Siesser, 1980). During this time, many rivers delivered less sediment to the coast or shut off entirely. Sedimentation offshore of Namibia became strongly influenced by both: deep oceanic circulation patterns, dominated by the Antarctic bottom water, and coastparallel currents such as the Benguela Current (Siesser, 1980).

Another factor favoring enhanced deposition and hence slumping is the upwelling high-productivity regime along the southwest African coast. The age assigned in this study to the first slide scarps corresponds well with the commencement of the upwelling regime, which is thought to be the result of trade-wind intensification as a response to growth of the east Antarctic ice sheet.

The westward shift of the slide scarp's location and lysocenter could indicate a shift of the upwelling front toward the west, and both can be related to a drop in relative sea level. Indeed, Siesser and Rogers (1976) found evidence for a brief westward shift in the offshore Benguela Current upwelling system during a brief regression close to the Miocene-Pliocene boundary ( $\sim 5.3 \mathrm{Ma}$ ). Siesser and Dingle (1981) described a major regression exposing much of the continental shelf during all of the Oligocene and early Miocene. This was followed by a transgression during the middle Miocene, which continued into the early Pliocene. If we accept this idea of slumping because of excess deposition beneath the upwelling front, we would expect to see mass-movement traces in the Miocene-Pliocene boundary and/or before early Miocene times (i.e., in and below unit SCB-3). Our observations are in contrast to this suggestion. We dated the scarps to represent events that have occurred since the middle Miocene, also during a phase of transgression.

Another possibility is that increased trade-wind activity transported surface waters offshore (e.g., Berger and Wefer, 2002). This would have forced the zone of upwelling filaments farther seaward and with it, the region of higher productivity and deposition. Support for this argument comes from TOC and $\mathrm{CaCO}_{3}$ levels found in the cores from sites 1085, 1086, and 1087. The drill sites are seaward of the main upwelling core, but contain material resulting from upwelling and transport to the drill sites (Meyers, 2001). The location of the observed slide scarps is also outside of the zone of modern coastal upwelling, but still within the range of upwelling filaments (Figure 3c). We prefer this scenario as an explanation for the observed occurrence and shift of slide scarps in the upper two seismic units SCB2 and SCB-1.

\section{CONCLUSIONS}

Based on our correlation of ODP Leg 175 sites 10851087 with seismic data, we established the following seismostratigraphic model for the sedimentary development of the southern Cape Basin. Four units, SCB-1 to SCB-4, were defined for the late Cenozoic sediments. The upper unit, SCB-1 (covering the last 1.5 Ma), reflects global cooling and glacial-interglacial cycles. We associate unit SCB-2 ( $\sim 14 \mathrm{Ma})$ with the onset of the modern circulation system in the Cape Basin. The two lowermost units, SCB-3 and SCB-4 (<56 Ma), indicate carbonate dissolution events. We believe they consist of shelf break material eroded and redeposited during a major regression spanning the entire Oligocene and early Miocene (Siesser and Dingle, 1981). The base of unit SCB-4 consists of a sequence of highamplitude reflectors, the lowermost of which we associate with the prominent reflector D of Emery et al. (1975) or L of Gerrard and Smith (1982).

In this study, we focused on mass movements in unit SCB-2, which is characterized by low-amplitude signals and numerous traces of slumping events. We date the buildup of unit SCB-2 to between 14 and $1.5 \mathrm{Ma}$. 
This interval plays a key role in our understanding of the present circulation system in the Cape Basin. Closure of the Panamanian oceanic gateway, growth of the polar ice caps, the development of modern wind and upwelling regimes, and the establishment of a modern ocean current system all took place since the early to middle Miocene (e.g., Wefer et al., 1998). The Antarctic ice sheet expanded in the middle Miocene. The resulting intensified trade winds are responsible for the establishment of the Benguela Current upwelling system. We interpret the low-amplitude reflection pattern and mass movements in unit SCB-2 to reflect enhanced production and deposition associated with the new upwelling regime.

Several possible causes for the occurrence of the mass-movement events and the seaward shift of their locations with time are considered. We interpret the mass movements to be a result of slope instability caused by increased sedimentation in response to a stepwise enhancement of the upwelling regime since the middle Miocene. Additionally, we believe scouring caused by the interaction of North Atlantic deep water and Antarctic intermediate water may have triggered mass movements. To explain the westward shift of scarp locations, we tentatively suggest a seawarddirected extension of the depocenters beneath upwelling filaments that migrated offshore because of increased trade-wind activity in the Miocene.

\section{REFERENCES CITED}

Austin, J. A. Jr., and E. Uchupi, 1982, Continental-oceanic crustal transition off Southwest Africa: AAPG Bulletin, v. 66, p. 1328 1347.

Berger, W. H., and G. Wefer, 1996, Expeditions into the past: Paleoceanographic studies in the south Atlantic, in G. Wefer, W. H. Berger, G. Siedler, and D. J. Webb, eds., The south Atlantic: Present and past circulation: Berlin, Springer-Verlag, p. 363-410.

Berger, W. H., and G. Wefer, 2002, On the reconstruction of upwelling history: Namibia upwelling in context: Marine Geology, v. 180 , p. $3-28$.

Bleil, U., and Shipboard Scientific Party, 1996, Report and preliminary results of Meteor cruise M34/1, Capetown-Walvis Bay, 3.1.1996-26.1.1996: Berichte aus dem Fachbereich Geowissenschaften, Universität Bremen, v. 77.

Bolli, H. M. and Shipboard Scientific Party, 1978, Cape Basin continental rise sites 360 and 361, in H. M. Bolli et al., eds., Initial Reports of the Deep Sea Drilling Project, v. 40, p. $29-$ 182.

Brown, L. F. Jr., J. M. Benson, G. J. Brinks, S. Doherty, A. Jollands, E. H. A. Jungslager, J. H. G. Keenan, A. Muntingh, and N. J. S. van Wyk, 1995, Sequence stratigraphy in offshore South African divergent basins, an atlas of exploration for Cretaceous lowstand traps by Soekor (Pty) Ltd, $184 \mathrm{p}$.
Diester-Haass, L., P. A. Meyers, and P. Rothe, 1992, The Benguela Current and associated upwelling on the southwest African margin: A synthesis of Neogene-Quaternary sedimentary record at DSDP sites 362 and 532, in C. P. Summerhayes, W. L. Prell, and K. C. Emeis, eds., Upwelling systems: Evolution since the early Miocene: Geological Society (London) Special Publication 64, p. 331-342.

Diester-Haass, L., P. A. Meyers, and L. Vidal, 2001a, The late Miocene onset of high productivity in the Benguela Current upwelling system as part of a global pattern: Marine Geology, v. 180 , p. $87-104$.

Diester-Haass, L., P. A. Meyers, L. Vidal, and G. Wefer, 2001b, Data report: Sand fraction, carbonate and organic carbon contents of Late Miocene sediments from site 1085, middle Cape Basin, in G. Wefer, W. H. Berger, and C. Richter, eds., Proceedings of the Oil Drilling Program, Scientific Results, Texas, College Station, v. 175, p. 1-23, http://www-odp.tamu.edu/publications/ 175_SR/chap_01/chap_01.htm (accessed January 26, 2004).

Dingle, R. V., and S. H. Robson, 1992, Southwestern African continental rise: Structural and sedimentary evolution, in W. Poag and de Graciansky, eds., Geologic evolution of Atlantic continental rifts: New York, Van Nostrand Reinhold, p. 62-75.

Emery, K. O., E. Uchupi, C. Bowin, J. Phillips, and E. S. W. Simpson, 1975, Continental margin off western Africa: Cape St. Francis (South Africa) to Walvis ridge (Southwest Africa): AAPG Bulletin, v. 59, p. 3-59.

Gerrard, I., and G. C. Smith, 1982, Post-Paleozoic succession and structures of the southwestern African continental margin, in J. S. Watkins and C. L. Drake, eds., Studies in continental margin geology: AAPG Memoir 34, p. 49-74.

Giraudeau, J., B. A. Christensen, O. Hermelin, C. B. Lange, I. Motoyama, and Shipboard Scientific Party, 1998, Biostratigraphic age models and sedimentation rates along the southwest African margin, in G. Wefer et al., eds., Proceedings of the Ocean Drilling Program, Initial Reports 175, p. 543-546.

Giraudeau, J., C. Pierre, and L. Herve, 2001a, A late Quarternary, high resolution record of planktonic foraminiferal species distribution in the southern Benguela region: Site 1087, in G. Wefer, W. H. Berger, and C. Richter, eds., Proceedings of the Oil Drilling Program, Scientific Results, College Station, Texas, v. 175 , p. 1-26, http://www-odp.tamu.edu/publications/ 175_SR/chap_07/chap_07.htm (accessed January 26, 2004).

Giraudeau, J., P. A. Meyers, and B. A. Christensen, 2001b, Accumulation of organic and inorganic carbon in PliocenePleistocene sediments along the SW African margin: Marine Geology, v. 180, p. 49-69.

Lutjeharms, J. R. E., and P. L. Stockton, 1987, Kinematics of the upwelling front off southern Africa: South African Journal of Marine Science, v. 5, p. 35-49.

Mackensen, A., and W. U. Ehrmann, 1992, Middle Eocene through early Oligocene climate history and paleoceanography in the southern Ocean: Stable oxygen and carbon isotopes from ODP sites on Maud rise and Kerguelen plateau: Marine Geology, v. 108, p. 1-27.

McMillan, I. K., 1990, Foraminiferal biostratigraphy of the Berremian to Miocene rocks of the KUDU 9A-1, 9A-2 and 9A-3 boreholes: Communications of the Geological Survey of Namibia, v. 6, p. 23-29.

Meyers, P. A., 2001, Miocene-Pleistocene sedimentary record of carbon burial under the Benguela Current upwelling system, southwestern margin of Africa, in G. Wefer, W. Berger, and C. Richter, eds., Proceedings of the Oil Drilling Program, Scientific Results, College Station, v. 175, p. 1-19, http://www-odp. tamu.edu/publications/175_SR/chap_06/chap_06.htm (accessed January 26, 2004).

Meyers, P. A., and R. S. Robinson, 2001, 2. Data report: Carbonate 
and organic carbon content of sediments from site 1087 , southern Cape Basin, in G. Wefer, W. Berger, and C. Richter, eds., Proceedings of the Oil Drilling Program, Scientific Results, College Station, Texas, v. 175, p. 1-11, http://www-odp. tamu.edu/publications/175_SR/chap_02/chap_02.htm (accessed January 26, 2004).

Partridge, T. C., and R. R. Maud, 1987, Geomorphic evolution of the southern Africa since the Mesozoic: South African Journal of Geology, v. 90, p. 179-208.

Sangree, J. B., and J. M. Widmier, 1979, Interpretation of depositional facies from seismic data: Geophysics, v. 44, no. 2, p. 131-160.

Shannon, L. V., 1985, The Benguela ecosystem: Part I. Evolution of the Benguela, physical features and processes: Oceanography and Marine Biology, v. 23, p. 105-182.

Siesser, W. G., 1980, Late Miocene origin of the Benguela upwelling system off northern Namibia: Science, v. 208, p. 283-285.

Siesser, W. G., and R. V. Dingle, 1981, Tertiary sea-level movements around southern Africa: Journal of Geology, v. 89, p. 83-96.

Siesser, W. G., and J. Rogers, 1976, Authigenic pyrite and gypsum in southwest African continental-slope sediments: Sedimentology, v. 23, p. $567-577$.

Stramma, L., and R. G. Peterson, 1989, Geostrophic transport in the Benguela Current region: Journal of Physical Oceanography, v. 19, p. 1440-1448.

Tucholke, B. E., and R. W. Embley, 1984, Cenozoic regional erosion of the abyssal floor off South Africa: AAPG Memoir 36 , p. $145-164$.

Uchupi, E., and K. O. Emery, 1972, Seismic reflection, magnetic, and gravity profiles of the eastern Atlantic continental margin and adjacent deep-sea floor: I. Cape Francis (South Africa), to Congo Canyon (Republic of Zaire): Woods Hole Oceanographic Institution, Reference No. 72-95, 8 sheets.

Wefer, G.,W. H. Berger, and C. Richter et al., 1998, Proceedings of Ocean Drilling Program, Initial Reports 175, College Station, Texas.

Zachos, J., M. Pagani, L. Sloan, E. Thomas, and K. Billups, 2001, Trends, rhythms, and aberrations in global climate $65 \mathrm{Ma}$ to Present: Science, v. 292, p. 686-693. 